\title{
BASE NACIONAL COMUM CURRICULAR E GRAMÁTICA: das controvérsias do currículo ao ensino de Língua Portuguesa
}

\author{
Hermes Talles dos Santos Brunieri \\ Universidade Federal da Paraíba - UFPB, Brasil
}

\begin{abstract}
Resumo
O ensino de gramática e de Língua Portuguesa vem sendo continuamente discutido no campo educacional brasileiro, a despeito das orientações de instituições governamentais e contribuições recentes das Ciências da Linguagem. Neste artigo, analisa-se e identifica-se a noção de gramática e como o trabalho gramatical é orientado pela Base Nacional Comum Curricular (BNCC). Para isso, discutese o que seja e os impactos da BNCC no contexto educacional brasileiro através de pressupostos investigativos qualitativos e de um estudo documental; reflete-se sobre o conceito de gramática; e examina-se as orientações presentes nesse documento sobre ensino de gramática. Por fim, compreende-se que a BNCC harmoniza orientações pedagógicas e metodológicas contraditórias entre si, permitindo o trabalho concomitante com o texto e com a frase como objeto de estudo. Também se identifica que a noção de gramática desse documento pauta-se na concepção tradicional e normativa. Palavras-chave: BNCC. Gramática. Ensino de Língua Portuguesa. Gramática Tradicional. Currículo de ensino.
\end{abstract}

\begin{abstract}
Grammar and Portuguese teaching has been continuously discussed in the Brazilian educational field despite the guidelines from government bodies and Language Sciences recent contributions. In this article, we aim to analyze and to identify the concept of grammar and how grammatical application is guided by the Common National Curriculum Base (BNCC). To do that, we discuss what it is and the impacts of BNCC in the Brazilian educational context through qualitative investigative assumptions and a documentary study; we reflect on concept of grammar; and we examine the guidelines of this document on grammar teaching. Lastly, we understand that the BNCC harmonizes pedagogical and methodological guidelines that initially differ from each other allowing the concomitant handling of the text and utterance as object of study. We also identify that on that document the notion of grammar is based on a traditional and normative conception.
\end{abstract}

Keywords: BNCC. Grammar. Portuguese language teaching. Traditional Grammar. Curriculum. 


\section{Introdução}

A discussão sobre gramática e ensino de Língua Portuguesa não é nova nem recente no campo educacional brasileiro. Aliás, é motivo de atenção e reflexão de professores, especialistas e teóricos da língua - e não só, há também jornalistas, advogados, políticos e, atualmente, youtubers que proferem comentários nitidamente leigos, porém problemáticos e, por conseguinte, influentes sobre o tema - desde a consolidação da Linguística enquanto área do conhecimento científico no cenário acadêmico brasileiro por volta dos anos de 1970 (ILARI, 1992). Muitos estudos, orientações e contribuições sobre essa relação foram desenvolvidos e divulgados ao longo das últimas décadas, porém essa questão ainda é problemática, visto que, dada minha experiência como formador de professores, seja na formação inicial ou continuada de docentes de língua, o entendimento do que seja gramática e, dele derivado, sua contribuição e relação com ensino de Língua Portuguesa ainda se fundamentam em noções vagas e, até mesmo, confusas, muitas vezes pautadas na experiência escolar dos próprios professores outrora como alunos ou, principalmente, naquelas presentes em livros didáticos.

Na década de 90 do século XX, os Parâmetros Curriculares Nacionais de Língua Portuguesa para os anos finais do Ensino Fundamental [PCN] (BRASIL, 1998), documento produzido por especialistas a partir das contribuições das Ciências da Linguagem, orientavam explicitamente: $a$. a defesa de que o ensino da língua materna deveria privilegiar estudos e análises textuais, pois é no texto que a língua de fato se materializa e se concretiza interativamente, além de ser autêntica representação da atividade linguística; e $b$. ao não emprego do modelo de ensino fundamentado no que se entende corriqueiramente por ensino gramatical nos moldes tradicionais.

Essa ênfase no texto como objeto fundamental de ensino (ROJO, 2008) trouxe ao processo de ensino e aprendizagem da língua materna nova forma de consideração das variantes linguísticas, uma vez que essas, formais e informais, ou padrão e não padrão, são consideradas adequadas ou inadequadas de acordo com questões linguísticas e discursivas próprias de cada texto, em íntima relação com o gênero discursivo/textual a que pertence e com o contexto sociocultural e histórico em que se realiza. Não se trata exclusivamente de ensinar uma ou outra variante linguística, mas de ensinar o uso linguístico de forma contextualizada (isto é, em textos) e relacionada à função, à situação e às características dos gêneros discursivos/textuais que influem na produção dos enunciados que se alinhavam intra e entre si e, consequentemente, tecem o texto.

Desse modo, o professor de língua materna, por meio de tal abordagem, para ensinar gramática precisa considerar aspectos cotextuais e contextuais (linguísticos e extralinguísticos, respectivamente), a partir da inter-relação entre língua, gênero discursivo/textual e contexto interacional do texto com o qual está trabalhando. Essa abordagem, na prática, demanda que o professor domine não só conhecimentos gramaticais tradicionais e normativos, mas também de língua, texto, gêneros discursivos/textuais e como esses são influenciados pelo contexto de interação verbal. Nessa perspectiva, a gramática é 
sempre resultado de diferentes combinações entre esses níveis. Logo, é sempre contextualizada textualmente (ANTUNES, 2007, 2014).

Contudo, embora essas orientações tenham sido propostas ainda no final do século XX, o que se percebe é que o ensino gramatical, nas escolas brasileiras, apesar de já decorridas duas décadas do século XXI, mantém-se fortemente influenciado pela concepção tida como tradicionalista - focada na frase como objeto de ensino e baseada na Gramática Tradicional e Normativa. Nessa, o enfoque do ensino de gramática é basicamente orientado pelo conhecimento, identificação e categorização das partes da frase, principalmente das classes e subclasses morfológicas e sintáticas da língua. Associado a isso ocorre a prescrição linguística que consiste em ditar o que está ou não correto no uso da língua, a partir de preceitos oriundos de uma variante escrita idealizada, a norma-padrão. Nessa abordagem, o trabalho de leitura, interpretação e produção textual são praticamente vistos como desarticulados do ensino gramatical, mantendo a estrutura curricular de ensino de língua comum até os anos de 1960 no ensino escolar brasileiro através das disciplinas de retórica, poética e gramática (BUNZEN, 2006).

Assim, por mais que os PCN (BRASIL, 1998) objetivassem impactar o ensino de Língua Portuguesa, potencializando o texto e não mais a frase como objeto de ensino, tal tensão ainda permanece atual. Nesse sentido, no Brasil, entre outras questões que precisam ser discutidas em relação ao ensino da língua materna, a reflexão sobre o conceito de gramática e seus desdobramentos no ensino ainda é pertinente e necessário para contribuir com o ensino de língua materna na Educação Básica - mas não só.

Sendo a Base Nacional Comum Curricular [BNCC] (BRASIL, s/d $\mathrm{d}^{1}$ ) documento oficial que pretende, conforme explícito em sua introdução, orientar não só a construção de currículos de ensino pelos diferentes sistemas e redes educacionais brasileiros, mas também as propostas pedagógicas das instituições escolares, e principalmente pelo forte destaque que esse documento vem recebendo no contexto educacional brasileiro contemporâneo, objetivo, neste artigo, analisar e identificar a noção de gramática e como o trabalho gramatical é orientado pela BNCC.

Para tanto, partindo de pressupostos investigativos qualitativos e de um estudo documental (CHIZZOTTI, 2009; GIL, 2010; MARCONI; LAKATOS, 2010), considero relevante compreender o que seja e os impactos da BNCC no contexto educacional brasileiro, refletir sobre o conceito de gramática a partir das Ciências da Linguagem, e examinar as orientações presentes na BNCC sobre ensino gramatical. Por isso, primeiro faço breve explicação sobre tal documento, centrando-me na noção de currículo de ensino. Depois, desenvolvo uma discussão sobre o que seja gramática, apresentando três formas de sua compreensão e, a partir dessas, enfatizo uma abordagem que acredito ser mais proveitosa para o ensino. Na sequência, analiso partes do texto sobre a área de Linguagem e, especificamente, o componente curricular Língua Portuguesa da BNCC, procurando identificar e comentar o entendimento de gramática e sua influência no ensino de língua materna. Por fim, teço comentários com base na análise e reflexões construídas ao longo deste artigo. 


\section{BNCC: o que é e o que quer?}

A BNCC (BRASIL, s/d) - como é corriqueiramente conhecida e mencionada - é um documento oficial do governo federal brasileiro, previsto na Lei de Diretrizes e Bases da Educação Nacional [LDB] (BRASIL, 1996), e que visa a consolidar as proposições da Resolução nº 4, de 13 de julho de 2010, da Câmara de Educação Básica do Conselho Nacional de Educação, que definiu as Diretrizes Curriculares Nacionais Gerais da Educação Básica (DCN), alterando, em certo sentido, a educação brasileira, dada às mudanças e transformações culturais, sociais, contextuais e tecnológicas ocorridas neste país e no mundo ao longo das últimas décadas, e pretendeu padronizar os currículos educacionais dos diferentes sistemas e redes brasileiros de ensino.

Trata-se de um documento, ao menos no discurso oficial do Ministério da Educação (MEC), construído colaborativa e democraticamente, através de ampla participação de diversos setores sociais direta ou indiretamente ligados à educação na discussão e elaboração das várias versões até chegar a sua, aparente, versão final, homologada em 2018 - visto que não há data de publicação nem ficha catalográfica nas edições disponíveis para a Educação Básica no sítio eletrônico do mencionado ministério. Esse processo e modelo de elaboração são, no mínimo, inéditos na história da construção de documentos governamentais oficiais para a educação brasileira.

A BNCC é um documento - como prediz seu próprio nome - basilar. Não se trata de um currículo em si (MACEDO, 2018), mas de uma “[...] referência nacional para a formulação dos currículos dos sistemas e das redes escolares dos Estados, do Distrito Federal e dos Municípios e das propostas pedagógicas das instituições escolares [...]” (BRASIL, s/d, p. 8). Trata-se, portanto, de um documento oficial nacional de referência sobre o qual se deve pautar a construção dos currículos locais de ensino, bem como das propostas pedagógicas das escolas brasileiras. Os diferentes sistemas e redes de ensino do país deverão elaborar seus próprios currículos a partir das proposições da BNCC, mas também de suas demandas socioculturais e históricas locais (BRASIL, 2017). A BNCC é um documento normativo, isto é, orienta e estabelece o que deve ser ensinado e aprendido ao longo de toda Educação Básica no Brasil. Não se trata de uma imposição, mas, em certo sentido, de um guia. Contudo não é possível desconsiderar o que foi nele estabelecido.

É interessante notar que, embora não seja, em si, um currículo de ensino, a BNCC pode se tornar em um, pois esse documento detalha esmiuçadamente os conhecimentos essenciais que devem ser ensinados e aprendidos, em nível nacional, pelos estudantes regularmente matriculados na Educação Básica, a partir de competências e habilidades organizadas por área do conhecimento, componente curricular e ano(s) escolar(es).

Assim, conquanto possa parecer fácil entender o que seja e a proposta da BNCC, na prática, o que temos é, particularmente, a transformação quase que diretamente desse documento em currículos de ensino. Basta cotejar currículos estaduais implementados por diferentes unidades federativas como Minas Gerais (s/d), Paraná (2018) e São Paulo (s/d)² e 
veremos que, em alguma de suas partes, o detalhamento proposto na BNCC em relação às competências e habilidades repete-se conforme os anos escolares, com pequenas variações na redação do texto:

Quadro 1 - Cotejo entre BNCC e Currículo Referência de MG.

\begin{tabular}{|c|c|c|c|}
\hline \multicolumn{2}{|c|}{ BNCC (BRASIL, s/a, p. 168-169) } & \multicolumn{2}{|c|}{$\begin{array}{l}\text { Currículo Referência de Minas Gerais (MINAS } \\
\text { GERAIS, s/d, p. 361) }\end{array}$} \\
\hline Anos e & & Anos escolares & Campos de Atuação \\
\hline $6^{\circ}$ e $7^{\circ}$ & $\begin{array}{l}\text { Campo das práticas de } \\
\text { estudo e pesquisa }\end{array}$ & $6^{\circ}$ & $\begin{array}{l}\text { Campo das práticas de } \\
\text { estudo e pesquisa }\end{array}$ \\
\hline Práticas de linguagem & $\begin{array}{c}\text { Objetos de } \\
\text { conhecimento }\end{array}$ & Práticas de linguagem & de \\
\hline $\begin{array}{r}\mathrm{Ar} \\
\text { Linguístic }\end{array}$ & $\begin{array}{l}\text { ação } \\
\text { emática }\end{array}$ & $\begin{array}{l}\text { álise } \\
\text { a/Semiótica }\end{array}$ & $\begin{array}{r}\text { T } \\
\text { Prog }\end{array}$ \\
\hline \multicolumn{2}{|c|}{ Habilidades ${ }^{3}$} & \multicolumn{2}{|c|}{ Habilidades } \\
\hline \multicolumn{2}{|c|}{$\begin{array}{l}\text { (EF67LP25) Reconhecer e utilizar os critérios de } \\
\text { organização tópica (do geral para o específico, do } \\
\text { específico para o geral etc.), as marcas linguísticas } \\
\text { dessa organização (marcadores de ordenação e } \\
\text { enumeração, de explicação, definição e } \\
\text { exemplificação, por exemplo) e os mecanismos de } \\
\text { paráfrase, de maneira a organizar mais } \\
\text { adequadamente a coesão e a progressão temática de } \\
\text { seus textos. }\end{array}$} & \multicolumn{2}{|c|}{$\begin{array}{l}\text { (EF67LP25) Reconhecer e utilizar os critérios de } \\
\text { organização tópica (do geral para o específico, do } \\
\text { específico para o geral etc.), as marcas linguísticas } \\
\text { dessa organização (marcadores de ordenação e } \\
\text { enumeração, de explicação, definição e } \\
\text { exemplificação, por exemplo) e os mecanismos de } \\
\text { paráfrase, de maneira a organizar mais } \\
\text { adequadamente a coesão e a progressão temática de } \\
\text { seus textos }\end{array}$} \\
\hline
\end{tabular}

Fonte: Elaborado pelo autor.

Quadro 2 - Cotejo entre Referencial Curricular do Paraná e Currículo Paulista.

\begin{tabular}{|c|c|c|c|}
\hline \multicolumn{2}{|c|}{$\begin{array}{c}\text { Referencial Curricular do Paraná (PARANÁ, } \\
2018, \text { p. 667) }\end{array}$} & \multicolumn{2}{|c|}{ Currículo Paulista (SÃO PAULO, s/d, p. 185) } \\
\hline Anos escolares & Campos de Atuação & Anos escolares & Campos de Atuação \\
\hline $6^{\circ}$ & $\begin{array}{l}\text { Campo das práticas de } \\
\text { estudo e pesquisa }\end{array}$ & $6^{\circ}$ e $7^{\circ}$ & $\begin{array}{c}\text { Todos os campos de } \\
\text { atuação }\end{array}$ \\
\hline Práticas de linguagem & Objetos de conhecimento & Práticas de linguagem & $\begin{array}{c}\text { Objetos de } \\
\text { conhecimento }\end{array}$ \\
\hline $\begin{array}{c}\text { Análise } \\
\text { Linguística/Semiótica }\end{array}$ & $\begin{array}{l}\text { Textualização } \\
\text { Progressão temática }\end{array}$ & $\begin{array}{l}\text { Leitura / escuta } \\
\text { (compartilhada e } \\
\text { autônoma) }\end{array}$ & $\begin{array}{l}\text { Textualização } \\
\text { Progressão temática }\end{array}$ \\
\hline \multicolumn{2}{|c|}{ Objetivos de aprendizagem (e desenvolvimento) } & \multicolumn{2}{|c|}{ Habilidades } \\
\hline \multicolumn{2}{|c|}{$\begin{array}{l}\text { (EF67LP25) Reconhecer e utilizar os critérios de } \\
\text { organização tópica (do geral para o específico, do } \\
\text { específico para o geral etc.), as marcas linguísticas } \\
\text { dessa organização (marcadores de ordenação e }\end{array}$} & \multicolumn{2}{|c|}{$\begin{array}{l}\text { (EF67LP25A) Reconhecer o emprego da coesão e da } \\
\text { progressão temática nas produções textuais. }\end{array}$} \\
\hline
\end{tabular}


enumeração, de explicação, definição e exemplificação, por exemplo) e os mecanismos de paráfrase, de maneira a organizar mais adequadamente

a coesão e a progressão temática de seus textos.

Reconhecer e utilizar os critérios de organização tópica, as marcas linguísticas dessa organização e os mecanismos de paráfrase, de maneira a organizar mais adequadamente a coesão e a progressão temática de seus textos.

Fonte: Elaborado pelo autor.

Ao analisar os excertos apresentados anteriormente, notar-se-á que os títulos dos documentos estaduais variam entre si, mas mantêm explícita a associação à noção de currículo (de ensino). A organização também é muito semelhante entre eles, inclusive com divisões e com codificação das habilidades praticamente idênticas. Ademais, observa-se que o documento mineiro é o mais próximo da BNCC, com exceção do desmembramento do ano escolar em único e não composto; o documento paranaense também desmembra o ano escolar e transforma as habilidades previstas na BNCC em objetivos de aprendizagem, acrescentando ainda novo objetivo, derivado da habilidade prevista no documento de referência; e o documento paulista modifica o campo de atuação, as práticas de linguagem e desmembra e reescreve as habilidades, mantendo relação, mesmo assim, com a BNCC. Como exposto, no todo, os textos dos currículos locais, pelo menos nas descrições das competências e habilidades, são bem semelhantes ao mencionado documento oficial nacional.

Esses exemplos permitem a reflexão de como, no Brasil, a elaboração ou a adequação de currículos de ensino pelos diferentes sistemas e redes escolares podem efetivamente ocorrer a partir da BNCC, porquanto há corriqueiramente a compreensão de que o currículo de ensino deve ser um documento que traga o que e quando deve ser ensinado (GOODSON, 1995), ou seja, algo já disponível no mencionado documento de referência. Isso também ocorre pela carência de uma reflexão profunda sobre o que seja currículo de ensino e como ele se concretiza no processo educacional, prevalecendo a noção corriqueira de que o currículo seria uma lista de conhecimentos a serem ensinados e cumprida pelos professores dentro de determinado período de tempo e não como algo composto por conhecimentos selecionados a partir de determinados pressupostos socioculturais de certo grupo ou sociedade para ser formalmente ensinados a (todos) seus membros, sob a justificativa de um projeto de transformação social e formação de sujeitos (GOODSON, 1995).

A BNCC, então, parece-me um busílis a sua intenção principal. Ao orientar a construção de currículos, ela também sugere o que deve ser trabalhado e o conhecimento que é previsto aos alunos em cada etapa. Nesse cenário, o bojo para construção dos currículos pelos diferentes sistemas e redes escolares fica limitado por conta da excessiva descrição e detalhamento sobre o que é esperado para cada ano ou ciclo escolar e de cada componente curricular. Logo, como vimos, os sistemas e redes locais de ensino astutamente se valeram dessa listagem e transformaram-na em currículos. 
Infelizmente, essa compreensão e construção de currículo faz com que o papel do professor e sua prática fiquem limitados e já preditos, em certo sentido, uma vez que por ter de desenvolver com seus alunos e fazê-los atingir competências e habilidades que já lhe foram impostas no currículo, fica mais fácil avaliar, interna e externamente, seu trabalho e desempenho. Há, assim, escamoteadamente a orientação de que basta cumprir o que foi detalhadamente previsto no currículo de ensino para se ter sucesso no processo de ensino e aprendizagem e, destarte, pressiona-se e responsabiliza-se o professor exclusivamente pelo sucesso ou não do currículo, das propostas de ensino locais ou nacionais e da aprendizagem discente.

A BNCC, portanto, enquanto base, isto é, alicerce para a construção de outros currículos, já parece, na verdade, entregar não só a fundação basilar, mas todo o corpo de um possível documento curricular. Obviamente, na própria lei, resolução e pareceres ${ }^{4}$ que a fundamentam, a orientação é de que a BNCC seja entendida como documento de referência, porém a prática já tem nos evidenciado de que está mais fácil adotá-la como currículo de ensino, o que demonstra uma grande contradição, uma vez que questões locais estão sendo desconsideradas, fazendo assim com que documentos dos sistemas e redes escolares sejam descolados da realidade local e, com isso, apenas cumpram demandas legais, sendo certamente inócuos para a educação mais uma vez. Parte disso, pode estar associado à noção de que padronizar os diferentes currículos educacionais brasileiros seja equivalente a tornálos iguais, uniformizá-los. Há, aí, um grande equívoco, pois a ideia central da BNCC seria articular, fazer com que os currículos locais convergissem entre si, mas mantendo as demandas de suas comunidades particulares.

Por fim, outro problema da BNCC enquanto um documento curricular de referência consiste nos conceitos e propostas nela inseridas sem ancoragem conceitual e que podem ser indistintamente aceitos ou mesmo considerados nos currículos locais e, assim, incentivar, reforçar ou reacender questões que há tempos vinham sendo debatidas com intuito de alterar certas práticas de ensino tidas como insatisfatórias. No caso do ensino da Língua Portuguesa, a apresentação e a construção do componente como um único bloco para os anos iniciais e finais do Ensino Fundamental são, ao mesmo tempo: avanço por propiciar aos professores pedagogos (ou generalistas) conhecerem a proposta dos anos finais e aos professores especialistas, a proposta dos anos iniciais, permitindo uma visão global do ensino da língua materna ao longo do Ensino Fundamental; e retrocesso por apresentar conceitos como alfabetização, letramento, práticas de linguagem, discurso, gêneros discursivos/gêneros textuais, esferas/campos de circulação dos discursos, atividade/comunicação/uso da linguagem, norma-padrão, linguagens (semioses), capacidades de leitura, produção e tratamento das linguagens etc. sem contextualização teórica e de forma superficial, parecendo pressupor que os professores já deveriam dominar tais conhecimentos específicos. Ao deixar tais conceitos vagos, permite-se a compreensão desses de forma dúbia ou equivocada.

Aliás, essa não ancoragem conceitual - visto que não há referenciação teórica - perpassa todos os componentes curriculares do mencionado documento, sendo, portanto, uma de suas características que permite, grosso modo, a consideração de que: ou se acredita que o 
professor será capaz de encontrar referências teóricas por si só; ou se desconsidera a necessidade de referenciar teoricamente certos conceitos. Nenhuma das duas é razoável, pois, conforme já exposto, tornam vaga a compreensão do professor e de outros profissionais e permitem compreensões conflitantes, equivocadas ou inadequadas, abrindo espaço para defesa de posições individuais, e não coletivas dentro das instituições de ensino.

Por isso, se mantido ou copiado o texto da BNCC pelas redes locais de ensino, há a potencialização ou a criação de espaço fértil para que profissionais dos anos iniciais ou finais assimilem tais conceitos a partir de suas convicções ou preconceitos, o que pode resultar ou validar práticas incoerentes com a proposta de ensino ou não legitimadas pela equipe profissional escolar, ou ainda pressões de um lado ao outro, a partir de suas convicções particulares. Além de abrir também a possibilidade de interferências descabidas e mais pressão à equipe profissional da educação por parte da comunidade externa.

Nesse sentido, principalmente no que concerne ao ensino gramatical, a BNCC pode ser perigosa e revigorar discussões positivas ou negativas a depender do nível de conhecimento e interesse dos professores de Língua Portuguesa e outros profissionais escolares, seja nos anos iniciais ou finais do Ensino Fundamental e mesmo no Ensino Médio. Por isso, procurando contribuir com o ensino de língua materna, na sequência, dedico-me à discussão sobre alguns conceitos de gramática.

\section{O que é mesmo gramática?}

Há diferentes concepções para o termo gramática. Contudo, baseando-me fundamentalmente em Franchi (1991), Neder (1993), Travaglia (2009) e Possenti (2012), dedicar-me-ei a explicar três conceitos de gramática: normativa, descritiva e internalizada. Por fim, a partir dessas explicações, aprofundarei e ampliarei a discussão sobre tal conceito, abordando uma outra maneira de se compreender gramática, que considero ser mais produtiva, uma vez que quero também, com este texto, contribuir com a reflexão dos docentes sobre o ensino de língua materna.

O primeiro conceito de gramática a ser apresentado compreende-a como “[...] conjunto de regras que devem ser seguidas” (POSSENTI, 2012, p. 64, grifos do autor). Como destacado pelo autor, há explicitado nessa abordagem o aspecto prescritivo. Por isso, essa gramática é conhecida como normativa a qual, como define Franchi (1991, p. 48), é “[...] o conjunto sistemático de normas para bem falar e escrever, estabelecidos pelos especialistas, com base no uso da língua consagrado pelos bons escritores”. Dessa definição destacam-se alguns termos que são centrais para o entendimento da concepção da mencionada gramática: conjunto sistemático, normas, bem falar e escrever, uso consagrado da língua, bons escritores. Quando se pensa na gramática normativa, devemos compreender que suas normas são um conjunto intencionalmente organizado de preceitos para regular uma variedade linguística (falada ou escrita) tida como de prestígio, a qual é estabelecida por gramáticos normativos a partir de escritores literários e que foi eleita como exemplar e modelar da língua culta. Essa eleição e prescrições são resultantes de aspectos não linguísticos, mas 
socioculturais e políticos, pois envolvem, geralmente, a língua falada pela classe dominante de determinada sociedade.

Travaglia (2009, p. 24, grifo do autor) assevera que essa “[...] gramática é concebida como um manual com regras de bom uso da língua a serem seguidas por aqueles que querem se expressar adequadamente”. Isso influencia historicamente o ensino da Língua Portuguesa através de um conjunto de preceitos (normas) a ser apreendido pelo estudante para que consiga falar e escrever corretamente a língua culta, que seria a que mais se aproximaria da norma-padrão definida pelos gramáticos normativos. Caso haja o rompimento (até mesmo por desconhecimento) desses preceitos, costuma-se compreender que o estudante ou o falante possui problemas para organizar mentalmente seus enunciados. Por isso, não é raro que essa gramática justifique preconceitos linguísticos e proporcione avaliações negativas em relação àqueles que não dominam a variedade culta da Língua Portuguesa ou que eventualmente desviem-se da norma-padrão.

O segundo conceito de gramática a define como "[...] conjunto de regras que são seguidas” (POSSENTI, 2012, p. 64, grifos do autor). Essa concepção orienta o trabalho de especialistas, principalmente linguistas, que procuram explicar o funcionamento linguístico por meio da descrição da língua em uso. Seu foco consiste nas regras que são seguidas ou utilizadas pelos falantes em suas interações verbais. Destaca-se, assim, a mudança de paradigma desta gramática, conhecida como descritiva, em relação àquela, normativa: não há a intenção de prescrever o uso considerado correto e modelar da língua, por meio de uma variedade muitas vezes idealizada; o intuito é descrever o uso de diferentes variedades linguísticas que conjuntamente compõem determinada língua, para explicá-las e compreendê-las. Por isso, Franchi (1991, p. 52) define-a como “[...] um sistema de noções mediante as quais se descrevem os fatos da língua, permitindo associar a cada expressão dessa língua uma descrição estrutural e estabelecer suas regras de uso, de modo a separar o que é gramatical do que não é gramatical”. Destacam-se nessa definição: fatos da língua, descrição estrutural, regras de uso, gramatical e não gramatical (agramatical).

Por se tratar de uma descrição e não de prescrição, o que se procura com essa abordagem é compreender os fatos da língua, isto é, a organização, os arranjos, as combinações possíveis no uso e, com isso, a constituição da língua, descrevendo, assim, sua estrutura e suas regras, o que permite considerar se determinada manifestação verbal é gramatical ou não. Por exemplo: as meninas estão alegres com seus balões ou as menina estão/está alegre com seus/seu balão $\square$ são consideradas gramaticais, pois não rompem com a estrutura e as regras de uso possíveis entre as variantes linguísticas conhecidas e utilizadas do português brasileiro; contudo: menines estão alegres com seus balões ou os menin[-] estar [-]ão [s]alegre com seus balões $\square$ são consideradas agramaticais. O primeiro exemplo (menines...) até pode vir a ser considerado como gramatical, por conta de crescente discussão da inclusão do [-e] como marca de gênero neutro na atualidade, mas a depender muito do contexto interacional. Já o segundo, ao romper drasticamente com a estrutura principalmente morfológica de formação lexical (no primeiro caso, não marcação do gênero do substantivo; no segundo, desinência de pessoa e tempo solta, não articulada ao verbo; e, no terceiro, sufixo 
de marcação de plural no lugar de sufixo), só pode ser considerado agramatical, independentemente do contexto interacional, porquanto ninguém constrói enunciados assim.

Nessa perspectiva, a gramática da língua pode ser deduzida a partir da análise de um conjunto de enunciados, os quais revelam o funcionamento linguístico, por meio da estruturação de seus elementos. Logo, ela é um dos componentes da língua. Assim, gramática está intimamente relacionada à estrutura e ao funcionamento linguístico, pois, a partir dela, enxertar-se-iam e combinar-se-iam discretamente elementos para a construção de enunciados. Como em um quebra-cabeça tais elementos teriam lugar previsto para seu encaixe.

No ensino, a gramática descritiva costuma orientar propostas que, partindo de exemplos reais de uso da língua, incentivam os aprendizes a depreender como ela funciona, por meio da análise e descrição de seus elementos constituintes. Segundo Neder (1993), valendo-se de exercícios estruturais, nesse ensino da língua, procura-se conduzir o estudante à aprendizagem dos elementos dentro sistema linguístico, como intuito de que o aluno internalize regras linguísticas diferentes daquelas que possui. Priorizam-se exercícios, de certa forma, mecânicos, que visam ao domínio da estrutura linguística, possibilitando, assim, a compreensão do funcionamento da língua.

O terceiro conceito compreende gramática como "[...] conjunto de regras que o falante da língua domina” (POSSENTI, 2012, p. 64, grifos do autor). Essa gramática passa a considerar não mais apenas a língua, mas a situa em constante relação ao falante e ao contexto de interação verbal. Nessa concepção, conforme pontua Franchi (1991, p. 54), “[...] gramática corresponde ao saber linguístico que o falante de uma língua desenvolve dentro de certos limites impostos pela sua própria dotação genética humana, em condições apropriadas de natureza social e antropológica”. Por se tratar de um saber linguístico, desenvolvido dentro de certos limites que a faculdade linguística humana proporciona aos falantes e em relação a sua comunidade social, essa gramática é conhecida como internalizada. Conforme pontuam Kleiman e Sepulveda (2012, p. 57), “[...] como esse sistema [de saberes linguísticos] surge, se ele é inato ou adquirido à medida que o falante é exposto aos usos da linguagem, ao discurso, divide os linguistas em escolas com trajetórias de pesquisa muito diferentes”. Essa distinção não me é aqui relevante, porém destaco que esses saberes linguísticos não requerem ensino formal, isto é, não dependem do processo de escolarização para serem aprendidos; nós, falantes de língua portuguesa com língua materna, aprendemo-los e interiorizamo-los desde nosso nascimento, em nossas interações linguísticas com outros falantes. Por isso, Travaglia (2009, p. 32) considera essa gramática como equivalente à competência linguística internalizada do falante, isto é, trata-se de “[...] o conjunto de regras que é dominado pelos falantes e que lhes proporciona o uso normal da língua [...]”. A gramática internalizada também pode ser entendida como um componente linguístico, isto é, conjunto de regras linguísticas que permitem ao falante interagir satisfatoriamente através do uso da língua.

Entretanto, diferentemente da gramática descritiva, em que o movimento é explicitar essas regras e o funcionamento linguístico, nesta, esses saberes são considerados implícitos ou inconscientes (TRAVAGLIA, 2009). Por isso, é importante compreender o destaque feito por Travaglia (2009, p. 32) de que "na verdade é essa gramática [internalizada] que é objeto 
de estudos de outros dois tipos de gramática, sobretudo da descritiva”, ou seja, a gramática descritiva procura justamente compreender a constituição da língua por meio da explicitação da gramática internalizada.

No ensino, a gramática internalizada é muitas vezes trabalhada de forma tácita, sem muita intencionalidade ou percepção pelo docente, uma vez que está envolvida em todas as atividades com a língua, seja de leitura/interpretação ou produção de textos. Por ser implícita, muitas vezes, os professores desconsideram que a compreensão ou produção de enunciados também se relaciona a saberes linguísticos implícitos sobre o conjunto de regras acerca do funcionamento da língua, isto é, que envolvem conhecimentos gramaticais. Por isso, o ensino gramatical só ocorreria para parte dos professores se houvesse a explicitação, por meio de classificação e categorização de partes ou elementos do discurso, principalmente, por meio da taxionomia da Gramática Tradicional.

Por isso, considero que as noções de atividades linguísticas, epilinguísticas e metalinguísticas possam contribuir para a ampliação e reflexão sobre o trabalho com gramática no ensino de Língua Portuguesa. Antes, preciso pontuar que atividade não diz respeito a exercícios ou propostas de ensino, mas à ação, a pôr a língua em ação. Segundo Franchi (2006), concerne às atividades linguísticas o exercício pleno, circunstanciado e intencional da linguagem em situações corriqueiras de comunicação social. Esse domínio implícito é resultado de uma apropriação consciente ou não da língua, conforme o falante tem contato com seu emprego em situações reais de comunicação. As atividades epilinguísticas se associam ao exercício de construção de textos (ou enunciados) mais complexos, comparando, transformando, experimentando e atribuindo novas significações a outras possibilidades de construções linguísticas (FRANCHI, 2006), de acordo com a situação comunicativa. Por fim, as atividades de metalinguagem consistem em fazer hipóteses sobre a própria linguagem e sobre o caráter sistemático das construções linguísticas, descrevendo-as em um quadro nocional intuitivo ou teórico.

Todas essas atividades envolvem necessariamente a gramática internalizada. A atividade linguística é algo espontâneo, contudo, para ocorrer, envolve, entre outros, saberes linguísticos dessa gramática. A atividade epilinguística demanda reflexão sobre o texto. É um trabalho mais intencional ou consciente com a língua, de forma a compreender e produzir enunciados. Embora ocorra, geralmente, de forma espontânea, no ensino, essa atividade precisa ser induzida, de forma que sua exploração potencialize a reflexão e a aprendizagem linguística. Já a atividade metalinguística consiste na descrição da língua, explicando-a, por meio não necessariamente de uma taxionomia preestabelecida. Esta também não é uma atividade espontânea, mas é costumeiramente a mais enfatizada ao longo da história ocidental e, ainda hoje, no processo de ensino de línguas.

A partir de tais reflexões, gostaria de discutir o conceito de gramática, baseando-me, principalmente, na consideração de que toda atividade linguística ocorre por meio de textos, os quais são construídos tensamente por fatores intra e extralinguísticos da atividade interacional em que ocorrem, isto é, toda interação verbal resulta de conhecimentos linguísticos e contextuais. 
É comum encontrarmos a seguinte explicação para o que seja gramática: “[...] conjunto de regras que definem o funcionamento de uma língua” (ANTUNES, 2007, p. 26). Como já exposto anteriormente, regra, aqui, não tem equivalência a preceito, isto é, algo prescritivo, norma externa à língua, como ocorre na gramática normativa. Regra resulta das regularidades encontradas no uso da língua. Por isso, relaciona-se a uso linguístico. Logo, é possível que elas sejam alteradas ou ampliadas devido às mudanças que normalmente ocorrem na língua. Elas são, portanto, estáveis, mas não imutáveis. Desse modo, como assevera Antunes (2007, p.26, grifo da autora),

[...] gramática abarca todas as regras de uso de uma língua. Envolve, portanto, desde os padrões de formação das sílabas, passando por aqueles outros de formação de palavras e de suas flexões, até aqueles níveis mais complexos de distribuição e arranjo das unidades para a constituição das frases e dos períodos. Nada na língua, em nenhuma língua, escapa a essa gramática.

A partir dessa definição, chamo a atenção para o seguinte ponto: é bastante comum, no processo de ensino de língua materna, o enfoque das regras gramaticais morfológicas e sintáticas, principalmente por conta de esses serem os níveis mais explorados pela Gramática Tradicional. Em alguns momentos, há até certa confusão por parte de alguns especialistas, que chegam a reduzir ou a equivaler gramática a morfologia e sintaxe. Em parte, essa visão também ocorre porque historicamente os estudos descritivos da língua se fundamentavam na corrente estruturalista que tendia a focar no estudo das unidades (fonologia e morfologia) constitutivas das frases e dos períodos (sintaxe).

Todavia, como bem destaca Antunes (2007), nada na língua escapa à gramática. Por isso, atualmente, conforme comenta Oliveira (2010), alguns gramáticos e linguistas defendem que as regras gramaticais não são apenas de ordem formal (isto é, morfossintáticas), mas também semântica (significado) e pragmática (uso). Considerando que um texto é resultante da língua em uso e que seus significados são oriundos das combinações entre as formas propiciadas pela língua e conhecidas pelos falantes, de acordo com as situações de interação verbal, faz todo sentido compreender que a gramática não se limita apenas às formas ou às estruturas linguísticas, mas também resulta do uso da língua em enunciados, o que contribui ativamente para a produção de sentidos de um texto em uma atividade interacional. A própria Antunes (2007, p. 26-27) ilustra essa inter-relação:

[...] Uma criança de 2 anos e quatro meses, ao ser interrogada se queria falar pelo telefone com a avó, respondeu prontamente:

- Quero.

Observemos que essa criança não disse “queremos”, “quis”, “querem”, nem outra coisa qualquer que não fizesse sentido nessa situação específica. Pelo contrário, usou o verbo nas flexões de tempo, modo, pessoa e número adequadas, omitiu o pronome sujeito, omitiu o complemento do verbo, uma vez que esses elementos estavam contidos no contexto da interação. Certamente, se a pergunta tivesse sido: 
- Quem quer falar com a vovó? - o garoto não teria omitido o pronome e teria respondido:

- Eu quero! - ou, simplesmente:

$-\mathrm{Eu}$ !

Esse trecho evidencia a relação existente entre as dimensões formal, semântica e pragmática na construção do texto e destaca como essas dimensões articulam a gramática e alinhavam-na no texto: a depender da intencionalidade dos enunciadores, o uso da língua envolverá determinada articulação gramatical para concretizar-se textualmente, sempre a depender do contexto de interação e do significado que se pretende produzir.

Com esse exemplo e com a discussão até aqui desenvolvida, creio que seja possível entender, como ressalta Antunes (2014, p. 24, grifos da autora), que "a gramática é um dos componentes de que se constitui uma língua. Um dos componentes, bem entendido. Não é o único nem o mais importante”. Assim, friso que gramática não pode ser equiparada a morfologia ou sintaxe (ou morfossintaxe). Esses são outros componentes da língua. Ela é um componente não tão explícito ou perceptível como a morfologia e a sintaxe, pois está, como já dito, ligada a um saber do falante e também às regularidades do uso da língua em situações e por determinado grupo social.

Ademais, chamo a atenção para o sentido de definir que aparece muitas vezes na conceituação de gramática. É preciso não confundir definir com pré-definir ou prédeterminar, pois a gramática não determina descontextualizada ou previamente as distribuições e construções morfossintáticas dos enunciados. Isso seria uma concepção tradicional e normativa de que a gramática pré-define qual elemento e o lugar dele em um enunciado, como se houvesse padronização prévia das construções linguísticas. Trata-se de uma visão idealizada, que não corresponde de fato à noção de definição gramatical.

Considero ser mais adequado compreender definir como delimitação de possíveis arranjos disponíveis na língua pelo seu uso social e de conhecimento do falante. Nesse sentido, a gramática é algo mais flexível e contribui para as construções dos enunciados durante a interação e conforme a intencionalidade pretendida pelo enunciador. A gramática, portanto, não é algo prévio e fixo, mas vai articulando e alinhavando os níveis formais, semânticos e pragmáticos dos enunciados em um texto sempre tensamente em relação ao contexto e à atividade comunicativa, conforme ilustrado anteriormente por Antunes (2007).

No ensino de língua na Educação Básica, acredito que compreender a gramática como delimitadora das construções linguísticas possibilita a promoção de situações de reflexão sobre o texto, sobre os enunciados concretos que o formam, investigando, problematizando e, principalmente, refletindo sobre as marcas linguísticas que ele traz e, principalmente, destacando a relação entre forma, sentido e uso, conforme bem destaca Antunes (2007) no exemplo anteriormente citado, da criança de 2 anos. Além de mitigar a compreensão coerente de gramática enquanto algo fixo, descontextualizado, restringente e somente normativo, situando-a textualmente e destacando sua relação com a intencionalidade do enunciador, dentro de determinada situação comunicativa em um contexto de interação verbal. 


\section{Como a BNCC aborda gramática e seu ensino?}

Antes de investigar a noção de gramática e como o trabalho gramatical é orientado pela BNCC, apresentarei algumas informações sobre processo de compilação dos dados aqui analisados.

Empregando um editor on-line de documentos de extensão portable document format (PDF), disponível na rede mundial de computadores, recortei o intervalo entre as páginas 63 e 191 da BNCC, de modo que o material de análise ficou composto pelo texto inicial de apresentação da área de conhecimento de Linguagens e pelo texto geral do componente curricular de Língua Portuguesa. Vale lembrar que, no mencionado documento, esses textos são subsequentes, por isso não houve quebra da numeração das páginas no intervalo recortado. Justifico essa ação por supor inicialmente que o texto sobre a mencionada área poderia trazer alguma consideração sobre gramática ou ensino gramatical - o que não se concretizou, conforme se verificará a seguir. Ademais, a escolha por analisar apenas o componente de Língua Portuguesa ocorreu devido ao foco de nosso texto ser o ensino de língua materna.

Depois, com ajuda da função pesquisa de palavras em documentos do editor de texto que utilizei, busquei as seguintes palavras-chave: gramática, gramatical/gramaticais e análise linguística - esta última, por conta de ser originalmente uma contraproposta ao ensino gramatical dito tradicional, mas que com o tempo passou a abrangê-lo, principalmente em livros didáticos de Língua Portuguesa contemporâneos (OLIVEIRA, 2010). Elas foram escolhidas por potencialmente indiciarem trechos em que pudesse haver considerações sobre gramática e ensino gramatical. Após essa procura, obtive os seguintes valores de ocorrências dessas palavras, que depois foram verificadas manualmente no texto:

Quadro 3 - Palavras-chave e total de ocorrências no trecho recortado da BNCC

\begin{tabular}{|c|c|}
\hline Palavras-chave & Ocorrências \\
\hline Gramática & 1 \\
\hline Gramatical & 2 \\
\hline Gramaticais & 13 \\
\hline Análise linguística & 37 \\
\hline
\end{tabular}

Fonte: Elaborado pelo autor.

Feito isso, recortei cada trecho em que essas palavras-chave ocorrem no material de análise e o transcrevi aqui, seguindo a ordem do quadro anterior. Entretanto, advirto que por conta do alto número de ocorrências da palavra-chave análise linguística, optei por transcrever e analisar apenas trechos em que ela ocorre nos textos explicativos do componente curricular e não nos quadros descritivos das competências e habilidades dos anos escolares. Isso não afeta minha análise, pois esses trechos dão conta da visão geral da BNCC sobre o trabalho com análise linguística. Com exceção do trecho em que ocorre a primeira 
palavra gramática - que aparece uma única vez -, todos os demais são numerados, conforme os tópicos, por um índice alfanumérico de modo a facilitar a retomada das análises realizadas.

Nas análises, como pode haver ocorrência de múltiplas palavras-chave, tecerei comentários apenas sobre aquela que foi destacada (sublinhada) para o tópico, de modo a facilitar minha apreciação. Destaco que farei uma análise qualitativa do conteúdo dos trechos selecionados.

\section{Gramática}

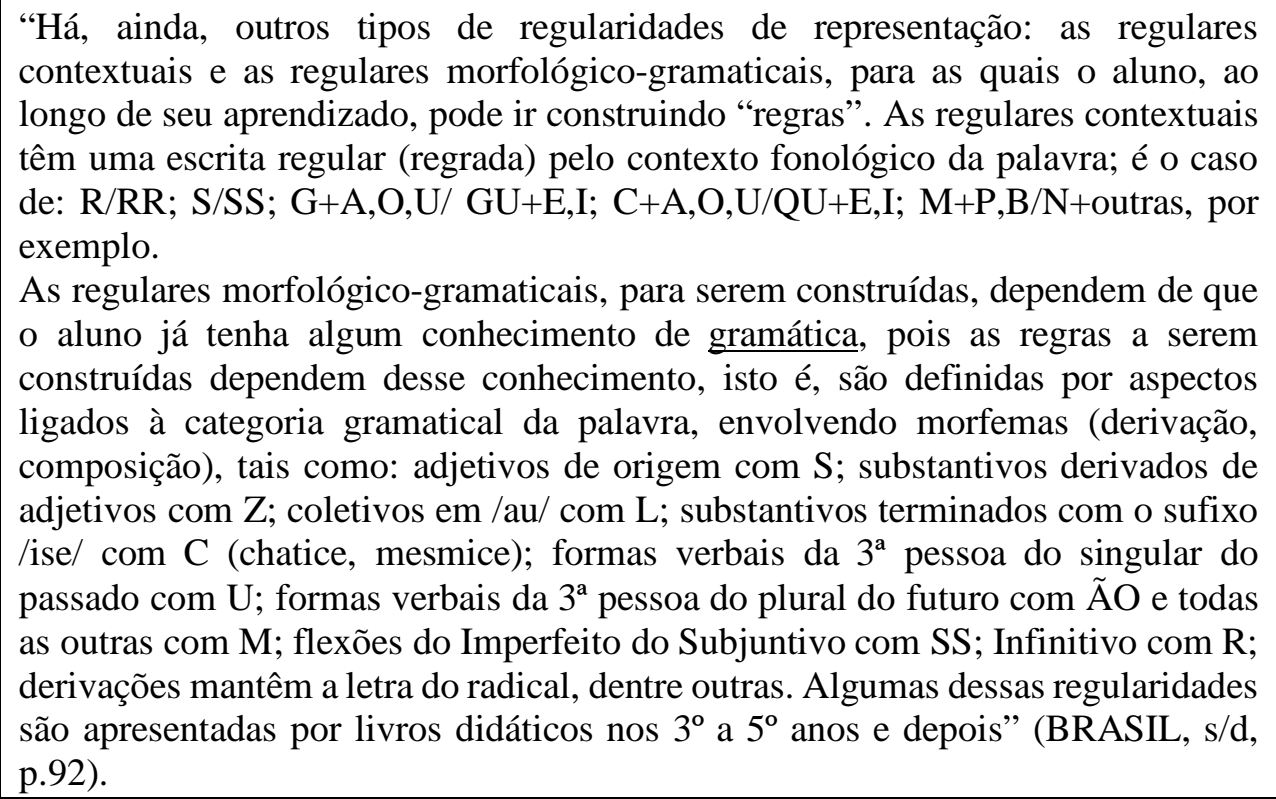

É preciso, antes de começar a comentar este trecho, indicar que ele se situa em um subitem, dentro do componente curricular de Língua Portuguesa, que é intitulado como $O$ processo de alfabetização. Há aí uma questão interessante: trata-se da única vez em que o termo gramática aparece no material analisado e ele ocorre justamente em um trecho que trata especificamente do processo de alfabetização.

Esse trecho aborda regras oriundas das regularidades ortográficas da escrita alfabética. O termo gramática aparece associado às regularidades de representação morfológicogramaticais que são aquelas, conforme o próprio excerto, relacionadas a construções lexicais. Nas exemplificações fica claro que gramática concerne ao conhecimento das regras morfológicas de construção lexical. Entretanto, é preciso aqui destacar que não há correspondência direta entre léxico e escrita, pois o primeiro é um fenômeno linguístico e o segundo é uma representação linguística. Essa representação escrita da constituição lexical é arbitrária, o que de fato causa muita dificuldade aos estudantes, principalmente no período de alfabetização, uma vez que eles tendem a transcrever as palavras conforme as percebem sonoramente através da escuta. 
Como se percebe, a palavra gramática é empregada neste trecho sem qualquer especificação, parecendo haver a pressuposição de que os docentes, nesse caso, professores dos anos iniciais do Ensino Fundamental, que geralmente não têm conhecimentos especializados das Ciências da Linguagem, já conheçam tal conceito linguístico.

Na sequência do texto, nas exemplificações, gramática pode ser entendida apenas como descrição morfológica quando, na verdade, nesse caso, está associada à construção lexical. Com isso, pode haver o reforço da gramática normativa ou descritiva. No primeiro caso, o professor, nesse processo de alfabetização, pode entender que, ao explicar regras morfológicas de construção lexical, contribua com o domínio da escrita alfabética. No segundo, que, ao explicitar tais regras, por meio de exercícios mecânicos, possa potencializar o processo de alfabetização. Em nenhum dos casos parece-me que haverá contribuição efetiva para a aprendizagem discente. Esse conhecimento ele já possui, por conta de sua gramática internalizada, diferentemente do que o mencionado trecho pontua. A depuração da escrita - digamos assim -, abordado no referido trecho, ocorrerá através do conhecimento da ortografia oficial da Língua Portuguesa brasileira associado aos conhecimentos gramaticais sobre léxico, mais focalizadamente, ao longo das séries iniciais e, depois, durante todo o processo escolar, conforme salientado no próprio excerto.

\section{Gramatical}

1B: “[...] Temos aí, portanto, o eixo da análise linguística/semiótica, que envolve o conhecimento sobre a língua, sobre a norma-padrão e sobre as outras semioses, que se desenvolve transversalmente aos dois eixos - leitura/escuta e produção oral, escrita e multissemiótica - e que envolve análise textual, gramatical, lexical, fonológica e das materialidades das outras semioses.” (BRASIL, s/d, p. 80)

2B: "As regulares morfológico-gramaticais, para serem construídas, dependem de que o aluno já tenha algum conhecimento de gramática, pois as regras a serem construídas dependem desse conhecimento, isto é, são definidas por aspectos ligados à categoria gramatical da palavra, envolvendo morfemas (derivação, composição) [...]” (BRASIL, s/d,p. 92).

O primeiro trecho (1B) ocorre no texto explicativo do componente curricular de Língua Portuguesa. O segundo (2B), como já demarcado anteriormente, em um subitem que trata do processo de alfabetização.

É interessante notar que em 1B trata-se de análise linguística/semiótica. Após explicar, grosso modo, o que seria essa análise, detalha-se que ela envolve análise textual, gramatical, lexical e fonológica, no que concerne a aspectos linguísticos. Chama-me a atenção tal desmembramento do geral para o específico: texto $\square$ fone. Possivelmente isso ocorra para dar conta do processo de alfabetização, em que questões fonológicas são consideradas em alguns processos ou em determinadas situações de aprendizagem da escrita. Contudo, também é interessante notar que gramática ocorre justamente entre texto e léxico, como se fosse menor que aquele e maior que este. Esse trecho pode sugerir que a gramática está 
inserida no texto, mas também que seja algo externo, autônomo em relação a ele. Além disso, não podemos nos esquecer de que ela também está no léxico e na fonologia. Esse destaque é estranho, a não ser que se entenda gramática como categorização sintática ou morfológica, como ocorre em 2B. Nesse caso, gramática relaciona-se às categorias, geralmente com base na gramática tradicional, sintáticas (sujeito, predicado; adjuntos, complementos, orações, períodos...) e morfológicas (substantivo, adjetivo, verbo...).

A redação de $1 \mathrm{~B}$ também possibilita o entendimento de gramática como um componente autônomo da língua, apesar de que, mesmo em uma visão tradicional, ela ocorre na sintaxe e na morfologia (a qual abrange léxico). Por sua vez, 2B apresenta justamente a noção de gramática tradicional, que, muitas vezes, também está relacionada à gramática normativa. Destarte, dadas as redações desses trechos, tem-se a indicação de gramática como algo externo à língua, como reguladora, não como interna, constituinte linguístico e relacionada à articulação dos enunciados, desde o léxico até a materialização textual. Isso denuncia que o foco do ensino gramatical na BNCC ainda é a frase, e não o texto, como recomendavam os Parâmetros Curriculares Nacionais (BRASIL, 1998).

\section{Gramaticais}

1C: (Eixo - Produção textual ${ }^{5}$ ) "Aspectos notacionais e gramaticais: Utilizar, ao produzir textos, os conhecimentos dos aspectos notacionais - ortografia padrão, pontuação adequada, mecanismos de concordância nominal e verbal, regência verbal etc., sempre que o contexto exigir o uso da norma-padrão" (BRASIL, s/d, p. 77).

2C: (Eixo - Análise Linguística/Semiótica) "O mesmo cabe às habilidades de análise linguística/semiótica, cuja maioria foi incluída de forma articulada às habilidades relativas às práticas de uso - leitura/escuta e produção de textos. São apresentados em quadro referente a todos os campos os conhecimentos linguísticos relacionados a ortografia, pontuação, conhecimentos gramaticais (morfológicos, sintáticos, semânticos) [...]” (BRASIL, s/d, p.82).

3C: (Eixo - Análise Linguística/Semiótica) "Morfossintaxe ${ }^{6}$ : Conhecer as classes de palavras abertas (substantivos, verbos, adjetivos e advérbios) e fechadas (artigos, numerais, preposições, conjunções, pronomes) e analisar suas funções sintático-semânticas nas orações e seu funcionamento (concordância, regência). • Perceber o funcionamento das flexões (número, gênero, tempo, pessoa etc.) de classes gramaticais em orações (concordância). - Correlacionar as classes de palavras com as funções sintáticas (sujeito, predicado, objeto, modificador etc.)" (BRASIL, s/d, p. 83).

4C: (Alfabetização) "Há, ainda, outros tipos de regularidades de representação: as regulares contextuais e as regulares morfológico-gramaticais, para as quais o aluno, ao longo de seu aprendizado, pode ir construindo "regras". As regulares contextuais têm uma escrita regular (regrada) pelo contexto fonológico da palavra; é o caso de: R/RR; S/SS; G+A,O,U/ GU+E,I; C+A,O,U/QU+E,I; $\mathrm{M}+\mathrm{P}, \mathrm{B} / \mathrm{N}+$ outras, por exemplo” (BRASIL, s/d, p.92). 
5C: (Alfabetização) “As regulares morfológico-gramaticais, para serem construídas, dependem de que o aluno já tenha algum conhecimento de gramática, pois as regras a serem construídas dependem desse conhecimento, isto é, são definidas por aspectos ligados à categoria gramatical da palavra, envolvendo morfemas (derivação, composição) [...]” (BRASIL, s/d, p. 92).

6C: (Quadro de habilidades do $2^{\circ}$ ciclo do EF) “(EF35LP07) Utilizar, ao produzir um texto, conhecimentos linguísticos e gramaticais, tais como ortografia, regras básicas de concordância nominal e verbal, pontuação (ponto final, ponto de exclamação, ponto de interrogação, vírgulas em enumerações) e pontuação do discurso direto, quando for o caso" (BRASIL, s/d, p. 113).

7C: (Quadro de habilidades do $2^{\circ}$ ciclo do EF - especificamente para o $5^{\circ}$ ano) “(EF05LP22) Ler e compreender verbetes de dicionário, identificando a estrutura, as informações gramaticais (significado de abreviaturas) e as informações semânticas” (BRASIL, s/d, p. 129).

8C: (Quadro de habilidades do $2^{\circ}$ ciclo do EF - especificamente para o $5^{\circ}$ ano) "(EF05LP26) Utilizar, ao produzir o texto, conhecimentos linguísticos e gramaticais: regras sintáticas de concordância nominal e verbal, convenções de escrita de citações, pontuação (ponto final, dois-pontos, vírgulas em enumerações) e regras ortográficas” (BRASIL, s/d, p. 131).

9C: (Quadro geral de habilidades do $3^{\circ}$ e $4^{\circ}$ ciclos do EF) “(EF69LP47) Analisar, em textos narrativos ficcionais, as diferentes formas de composição próprias de cada gênero, os recursos coesivos que constroem a passagem do tempo e articulam suas partes, a escolha lexical típica de cada gênero para a caracterização dos cenários e dos personagens e os efeitos de sentido decorrentes dos tempos verbais, dos tipos de discurso, dos verbos de enunciação e das variedades linguísticas (no discurso direto, se houver) empregados, identificando o enredo e o foco narrativo e percebendo como se estrutura a narrativa nos diferentes gêneros e os efeitos de sentido decorrentes do foco narrativo típico de cada gênero, da caracterização dos espaços físico e psicológico e dos tempos cronológico e psicológico, das diferentes vozes no texto (do narrador, de personagens em discurso direto e indireto), do uso de pontuação expressiva, palavras e expressões conotativas e processos figurativos e do uso de recursos linguístico-gramaticais próprios a cada gênero narrativo" (BRASIL, s/d, p. 159).

10C: (Quadro de habilidades do $3^{\circ}$ ciclo do EF - especificamente para o $7^{\circ}$ ano) "(EF07LP10) Utilizar, ao produzir texto, conhecimentos linguísticos e gramaticais: modos e tempos verbais, concordância nominal e verbal, pontuação etc.” (BRASIL, s/d, p. 173).

11C: (Quadro de habilidades do $3^{\circ}$ ciclo do EF - especificamente para o $6^{\circ}$ ano) "(EF06LP11) Utilizar, ao produzir texto, conhecimentos linguísticos e gramaticais: tempos verbais, concordância nominal e verbal, regras ortográficas, pontuação etc.” (BRASIL, s/d, p. 173).

12C: (Quadro de habilidades do $4^{\circ}$ ciclo do EF) “(EF89LP16) Analisar a modalização realizada em textos noticiosos e argumentativos, por meio das modalidades apreciativas, viabilizadas por classes e estruturas gramaticais como adjetivos, locuções adjetivas, advérbios, locuções adverbiais, orações adjetivas e 
adverbiais, orações relativas restritivas e explicativas etc., de maneira a perceber a apreciação ideológica sobre os fatos noticiados ou as posições implícitas ou assumidas” (BRASIL, s/d, p. 181).

13C: (Quadro de habilidades do $4^{\circ}$ ciclo do EF - especificamente para o $8^{\circ}$ ano) “(EF08LP04) Utilizar, ao produzir texto, conhecimentos linguísticos e gramaticais: ortografia, regências e concordâncias nominal e verbal, modos e tempos verbais, pontuação etc.” (BRASIL, s/d, p. 187).

Em todos os trechos listados anteriormente, é possível constatar que o termo gramaticais está de alguma forma relacionado à gramática tradicional e normativa. A primeira tem como base a frase como unidade de análise, por isso o foco recai sobre classes de palavras, estruturas e funções sintáticas, e suas respectivas categorizações ou classificações. A segunda, como já explicitado, prescreve como deve ser o uso de determinada variante linguística, por isso reiteradamente enfoca regência e concordância nominal, verbal ou verbonominal para trabalhá-las conforme suas prescrições. Esse enfoque prescritivo também recai sobre aspectos notacionais da escrita acerca da padronização ortográfica e da pontuação.

Em 7C, espera-se que o estudante seja capaz de compreender as abreviações sobre categorização gramatical, geralmente tendo por base a gramática tradicional, presentes nos verbetes dos dicionários. A meu ver, sim, isso é importante de ser aprendido no processo de escolarização, contudo, não nos primeiros anos do Ensino Fundamental. Como uma atividade metalinguística de compreensão de tais informações contribuirá para o processo de leitura e produção de texto, ou mesmo de análise linguística pelo estudante nessa fase escolar? Minha experiência profissional docente deduz que causará mais confusão à criança do que aprendizagem. Além disso, possibilita-se que o professor do $5^{\circ}$ ano se preocupe em - e também seja cobrado por - apresentar classificações, categorizações e nomenclaturas gramaticais tradicionais que serão, muito certamente, retomadas continuamente nos anos finais do Ensino Fundamental. Ou seja, com isso, o estudo da gramática como algo externo à língua e análises e classificações segundo a gramática tradicional adentram os primeiros anos escolares e o estudo do texto como objeto de ensino vai sendo postergado, pois o foco recai novamente no ensino gramatical apartado do texto e, assim, vai-se legitimando e se distanciando, como ocorrem em muitas escolas, as aulas de gramática das de redação (ou produção de texto), leitura e literatura.

Em 6C, 8C, 10C, 11C e 13C, encontram-se as expressões conhecimentos linguísticos e gramaticais. Essa divisão entre tais conhecimentos pela BNCC possibilita a compreensão de língua e gramática como fenômenos autônomos entre si. Como se houvesse conhecimentos que são próprios da língua e outros que o são da gramática. Isso é possível, se se entender gramática como conjunto de normas, que externamente à língua, prescrevem o uso de uma variante linguística idealizada, ou seja, a gramática normativa. Mesmo nesse caso, gramática e língua estão relacionadas, pois as normas daquela são aplicadas nesta. Contudo, como venho expondo neste artigo, a gramática faz parte da constituição da língua. Nesse sentido, essa separação é equivocada, se se pensar que os conhecimentos da gramática internalizada são conhecimentos sobre a língua que qualquer falante possui e que lhe possibilita interagir 
linguisticamente de modo satisfatório em diferentes situações comunicativas. Isso não quer dizer que gramática e língua são a mesma coisa. Aquela faz parte da constituição desta. Se se pensar na gramática descritiva, também não se terá muita base, pois todos os exemplos dados nos comentários ou nas explicações destes trechos rementem à Gramática Tradicional e Normativa.

Ao se observar os trechos listados anteriormente, é possível, por conta da redação, compreender que conhecimentos gramaticais concerniriam às regras sintáticas de regência e concordância, tempos e modos verbais; enquanto os conhecimentos linguísticos, às convenções da escrita, regras ortográficas e pontuação - o inverso também é possível. Embora pareça algo exagerado, ao examinar tais trechos, verifica-se que a exemplificação dos conhecimentos linguísticos e gramaticais trata de categorias comumente abordadas pela gramática tradicional (inclusive, empregando sua nomenclatura), que são geralmente considerados como gramaticais, enquanto aspectos relativos à notação da escrita não são muito associados a conhecimentos linguísticos. Todavia, como preencher de sentidos essa distinção? Uma possibilidade é essa. Outra, é entender que não há essa distinção e que tudo faz parte da língua, mas isso também, a meu ver, é exagerado, principalmente nos mencionados trechos, justamente por conta da distinção entre língua e gramática. Novamente, seria possível pensar em língua e sua gramática, se pensássemos em gramática descritiva ou internalizada, porém os trechos não possibilitam esse entendimento por focarem a Gramática Tradicional e Normativa.

Do ponto de vista das Ciências da Linguagem, é estranha essa dicotomia presente na BNCC, principalmente ao considerar a especificação de tais conhecimentos. No ensino, ela pode reforçar inadvertidamente a ideia de que conhecimentos linguísticos relacionam ao uso, à língua, ao texto, como se fossem mais amplos; já conhecimentos gramaticais, à estrutura, descrição e classificação das partes das frases. Consequentemente, isso corrobora com a manutenção da ideia de que é preciso estudar a gramática à parte, não inserida ou não como parte da produção textual e da leitura, enquanto atividade epilinguística ou apenas linguística. Volta-se, mais uma vez, à discussão anterior aos PCN (BRASIL, 1998) sobre o estudo da frase ou do texto.

Em 9C, há a expressão recursos linguístico-gramaticais. Aqui, diferentemente dos trechos analisados anteriormente, não se tem distinção, mas complementariedade. Além disso, não se trata de conhecimentos, que seriam mais cognitivos e da ordem do indivíduo, mas de recursos, isto é, meios disponíveis ao falante e da ordem da língua. Não há também exemplificação do que seriam esses recursos, porém eles estão, no trecho, relacionados aos gêneros narrativos.

Conquanto seja preciso destacar que não é usual encontrar essa expressão em textos da área de Ciências da Linguagem, nesse caso há a noção de que língua e gramática estão articuladas. Porém, isso é feito de forma tão vaga que, pela leitura de todo o texto da BNCC sobre o ensino de Língua Portuguesa, fica difícil que o leitor compreenda só por esse trecho essa relação. Ademais, geralmente são entendidos como recursos linguísticos marcadores coesivos, como anáfora e catáfora, ou, no caso dos gêneros narrativos, pronomes, para diferenciar narrador e personagens, advérbios de espaço e tempo, verbos de dizer, discurso 
direto e indireto... De fato, esses recursos são linguísticos e, por isso, também abrangem aspectos gramaticais, como, por exemplo, a marcação de modo e tempo nos verbos, todavia, isso só se efetiva através do uso da língua. Destarte, chama-nos a atenção a expressão recursos linguístico-gramaticais, a qual não é errônea, mas, a meu ver, é demasiada e tende a reiterar a importância do estudo gramatical tradicional nos anos finais do Ensino Fundamental.

\section{Análise Linguística ${ }^{7}$}

1D: "Considerando esse conjunto de princípios e pressupostos, os eixos de integração considerados na BNCC de Língua Portuguesa são aqueles já consagrados nos documentos curriculares da Área, correspondentes às práticas de linguagem: oralidade, leitura/escuta, produção (escrita e multissemiótica) e análise linguística/semiótica (que envolve conhecimentos linguísticos - sobre o sistema de escrita, o sistema da língua e a norma-padrão -, textuais, discursivos e sobre os modos de organização e os elementos de outras semioses). Cabe ressaltar, reiterando o movimento metodológico de documentos curriculares anteriores, que estudos de natureza teórica e metalinguística - sobre a língua, sobre a literatura, sobre a norma padrão e outras variedades da língua - não devem nesse nível de ensino ser tomados como um fim em si mesmo, devendo estar envolvidos em práticas de reflexão que permitam aos estudantes ampliarem suas capacidades de uso da língua/linguagens (em leitura e em produção) em práticas situadas de linguagem” (BRASIL, s/d, p. 71).

2D: "Se uma face do aprendizado da Língua Portuguesa decorre da efetiva atuação do estudante em práticas de linguagem que envolvem a leitura/escuta e a produção de textos orais, escritos e multissemióticos, situadas em campos de atuação específicos, a outra face provém da reflexão/análise sobre/da própria experiência de realização dessas práticas. Temos aí, portanto, o eixo da análise linguística/semiótica, que envolve o conhecimento sobre a língua, sobre a normapadrão e sobre as outras semioses, que se desenvolve transversalmente aos dois eixos - leitura/escuta e produção oral, escrita e multissemiótica - e que envolve análise textual, gramatical, lexical, fonológica e das materialidades das outras semioses” (BRASIL, s/d, p. 80).

3D: "O Eixo da Análise Linguística/Semiótica envolve os procedimentos e estratégias (meta)cognitivas de análise e avaliação consciente, durante os processos de leitura e de produção de textos (orais, escritos e multissemióticos), das materialidades dos textos, responsáveis por seus efeitos de sentido, seja no que se refere às formas de composição dos textos, determinadas pelos gêneros (orais, escritos e multissemióticos) e pela situação de produção, seja no que se refere aos estilos adotados nos textos, com forte impacto nos efeitos de sentido. Assim, no que diz respeito à linguagem verbal oral e escrita, as formas de composição dos textos dizem respeito à coesão, coerência e organização da progressão temática dos textos, influenciadas pela organização típica (forma de composição) do gênero em questão. No caso de textos orais, essa análise envolverá também os elementos próprios da fala - como ritmo, altura, intensidade, 
clareza de articulação, variedade linguística adotada, estilização etc. [...]. No que tange ao estilo, serão levadas em conta as escolhas de léxico e de variedade linguística ou estilização e alguns mecanismos sintáticos e morfológicos, de acordo com a situação de produção, a forma e o estilo de gênero.

$[\ldots]$

Os conhecimentos grafofônicos, ortográficos, lexicais, morfológicos, sintáticos, textuais, discursivos, sociolinguísticos e semióticos que operam nas análises linguísticas e semióticas necessárias à compreensão e à produção de linguagens estarão, concomitantemente, sendo construídos durante o Ensino Fundamental. Assim, as práticas de leitura/escuta e de produção de textos orais, escritos e multissemióticos oportunizam situações de reflexão sobre a língua e as linguagens de uma forma geral, em que essas descrições, conceitos e regras operam e nas quais serão concomitantemente construídos: comparação entre definições que permitam observar diferenças de recortes e ênfases na formulação de conceitos e regras; comparação de diferentes formas de dizer "a mesma coisa" e análise dos efeitos de sentido que essas formas podem trazer/ suscitar [...].” (BRASIL, s/d, p.80-81).

4D: “[...] Assim, para fins de organização do quadro de habilidades do componente, foi considerada a prática principal (eixo), mas uma mesma habilidade incluída no eixo Leitura pode também dizer respeito ao eixo Produção de textos e vice-versa. $\mathrm{O}$ mesmo cabe às habilidades de análise linguística/semiótica, cuja maioria foi incluída de forma articulada às habilidades relativas às práticas de uso - leitura/escuta e produção de textos” (BRASIL, s/d, p. 82).

5D: “[...] Assim, na BNCC, a organização das práticas de linguagem (leitura de textos, produção de textos, oralidade e análise linguística/semiótica) por campos de atuação aponta para a importância da contextualização do conhecimento escolar, para a ideia de que essas práticas derivam de situações da vida social e, ao mesmo tempo, precisam ser situadas em contextos significativos para os estudantes" (BRASIL, s/d, p. 84).

6D: “[...] Mas o mais importante a se ter em conta e que justifica sua presença como organizador do componente é que os campos de atuação permitem considerar as práticas de linguagem - leitura e produção de textos orais e escritos - que neles têm lugar em uma perspectiva situada, o que significa, nesse contexto, que o conhecimento metalinguístico e semiótico em jogo - conhecimento sobre os gêneros, as configurações textuais e os demais níveis de análise linguística e semiótica - deve poder ser revertido para situações significativas de uso e de análise para o uso" (BRASIL, s/d, p. 85).

7D: (Anos iniciais) "Assim, no Ensino Fundamental - Anos Iniciais, [...] no eixo Análise Linguística/Semiótica, sistematiza-se a alfabetização, particularmente nos dois primeiros anos, e desenvolvem-se, ao longo dos três anos seguintes, a observação das regularidades e a análise do funcionamento da língua e de outras linguagens e seus efeitos nos discursos [...]” (BRASIL, s/d, p. 89).

8D: (Anos iniciais) "[...] Do mesmo modo, os conhecimentos e a análise linguística e multissemiótica avançarão em outros aspectos notacionais da escrita, 
como pontuação e acentuação e introdução das classes morfológicas de palavras a partir do $3^{\circ}$ ano" (BRASIL, s/d, p. 93).

Pela leitura dos trechos listados anteriormente, como explicitado em 1D, a análise linguística é um dos eixos de integração do ensino de Língua Portuguesa, ou seja, o processo de ensino e aprendizagem da língua materna prevê a ocorrência intencional das práticas de linguagem de oralidade, leitura/escuta, produção e análise linguística. Assim, elas precisam estar articuladas na promoção da aprendizagem linguística e não pode haver a ocorrência de apenas uma delas durante todo o processo de ensino.

É importante destacar a questão da integração, conforme identificado nesse trecho. Geralmente, o que se tem nas escolas, principalmente nas privadas, são trabalhos isolados, conhecidos como frentes e com disciplinas escolares bem demarcadas em livros didáticos e na própria grade de aulas, que focam apenas gramática, literatura/leitura ou interpretação de texto e redação ou produção textual. Isso não atende o que está sendo proposto pela BNCC - pelo menos nesse trecho - para o ensino de língua, que é justamente o ensino articulado entre as práticas de ensino para que haja ampliação das capacidades dos estudantes de uso da língua em práticas situadas de linguagem (BRASIL, s/d).

Em 1D, tem-se que análise linguística envolve conhecimentos linguísticos, textuais e discursivos. Porém, os conhecimentos linguísticos são aqueles relacionados ao sistema de escrita, ao sistema da língua e à norma-padrão. Eles envolvem, portanto, escrita alfabética, gramática normativa e sistema da língua. O termo sistema é usado apenas nesse trecho e não é retomado ou especificado. É um termo amplo que pode sugerir a visão da língua como algo fechado e pronto, o que não é coerente com a proposta de se trabalhar com gêneros textuais, que estão baseados em uma perspectiva de língua em constante construção nas situações de interação. Na tentativa de especificar, gerou-se uma contradição aparentemente, pois sistema da língua, aí, pode também estar relacionado a uma visão de língua a partir das partes do discurso, conforme a gramática tradicional. Com isso, possibilitar-se-ia o trabalho com classes gramaticais, estruturas e funções sintáticas e as demais classificações e categorizações gramaticais tradicionais. Sistema também está relacionado a uma visão de língua como instrumento de comunicação, que não condiz à noção de gêneros textuais/discursivos e também não entende a língua a partir de partes do discurso.

Em 2D, depois de explicar a relação do eixo de análise linguística com o aprendizado da Língua Portuguesa por meio das práticas de linguagem, pontua-se que tal eixo envolve conhecimentos sobre a língua e a norma-padrão. É interessante pontuar: nesses trechos, há um recorrente destaque ao conhecimento da variante culta ou de prestígio da língua que se faz justamente por meio do ensino da norma-padrão. Só que, com isso, há escamoteadamente o reforço da ideia de que para se ensinar essa variante é preciso recuar, ou seja, ela não pode ser trabalhada em conjunto com as reflexões sobre a língua. Se se pensar que a norma-padrão é ensinada por meio da gramática normativa, conclui-se que haverá momentos no ensino da Língua Portuguesa em que será preciso trabalhar apenas com tal gramática. Assim, mais uma vez, vai-se afastando da noção de que o texto é o objeto de ensino e se caminhando para a 
frase, isto é, para trechos textuais que possibilitem a exemplificação e aplicação das prescrições gramaticais normativas.

O trecho 3D, ao explicar o desenvolvimento metodológico do eixo análise linguística, aproxima-se muito das atividades epilinguísticas e metalinguísticas propostas por Franchi (2006), o que é reforçado em 4D, 5D e 6D, ao pontuar que essa prática se insere em práticas de uso e reflexão sobre o uso linguístico. É interessante notar que, embora em 3D ocorra explícita e detalhadamente a proposição de um processo de ensino que preze pela reflexão intencional e motivada sobre a língua e a escrita alfabética em textos (ou em práticas de uso) como forma de promover a aprendizagem discente, minha análise demonstra que se trata de uma proposta isolada, que, no todo, não consegue ter força, principalmente porque há, de certa forma, o cultivo de espaços para a manutenção do ensino gramatical em perspectiva tradicional e normativa.

Por fim, em 7D e 8D, ao considerar a prática de análise linguística nos anos iniciais do Ensino Fundamental, destaca-se a relação dessa com o processo de apropriação da escrita alfabética, principalmente no primeiro ciclo, e do sistema de notação. Em 7D, retoma-se o papel dessa prática na reflexão sobre o uso da língua e, em 8D, declara-se que, a partir do $3^{\circ}$ ano, tal prática permite a introdução das classes morfológicas. Ou seja: a análise linguística serve também para o ensino de noções gramaticais tradicionais. Com isso, novamente se tem o espaço para a manutenção do ensino gramatical desarticulado do texto e através de uma perspectiva tradicional e normativa, infeliz e sarapantadamente já nos anos iniciais do Ensino Fundamental.

\section{Considerações finais}

Como procurei explicitar, a BNCC possui controvérsias seja em sua função de contribuir com a padronização dos currículos de ensino das diferentes instituições escolares brasileiras, seja em sua organização e conteúdo, no caso deste texto, do componente curricular de Língua Portuguesa. De antemão, quero explicitar que isso não desmerece ou invalida tal documento oficial, que, evidentemente, é de grande contribuição para o ensino e para a Educação Básica deste país. Todavia, destaco que as questões aqui analisadas precisariam ser revistas e reconsideradas de forma a aprimorar os objetivos e contribuições pretendidas inicialmente com a formulação e a construção de tal documento.

Enquanto base curricular, a BNCC é problemática justamente por detalhar demasiadamente o que se espera de conhecimento a ser desenvolvido em cada ano e etapa escolar nas descrições das competências e habilidades. Isso, indubitavelmente, facilita a avaliação em larga escala do rendimento estudantil, possibilitando aos gestores educacionais a construção de novas políticas. Contudo, dificulta ou impede a consideração de aspectos socioculturais locais que interferem e precisam ser abordados no processo de ensino e que estão diretamente ligados à educação dos estudantes. Como vimos, alguns currículos locais de referência já optaram por manter a estrutura e a organização prevista na BNCC, com isso aspectos locais foram, aparentemente, desconsiderados. Aposta-se, mais uma vez, na minha 
visão, no aspecto tecnicista e regulatório do currículo, que vem sendo insistido há tempos neste país, mas que não produziu ainda resultados satisfatórios, se considerarmos avaliações externas em larga escala como o PISA (Programme for International Student Assessment), tão em voga nesses últimos anos.

A BNCC também nos apresenta um texto que tenta aliar conhecimentos preconizados pelo campo científico, tradicionais existentes no contexto escolar e outros oriundos de diferentes setores da sociedade brasileira, procurando conciliá-los em um discurso aparentemente de vanguarda, que, por um lado, fundamenta-se em teorias de ensino e aprendizagem mais coerentes com a ciência e com a academia e, por outro, devido principalmente ao processo de consulta aos professores e de outros setores sociais, traz e assegura demandas de ensino coerentes com as proposições dos docentes e com desejos e crenças de parte da sociedade. Com isso, a BNCC articula no ensino de Língua Portuguesa, de um ponto de vista macro, orientações pedagógicas e metodológicas distintas: de um lado o texto e de outro a frase como objeto de ensino. Essa articulação aparentemente harmoniosa agrada, em certo sentido, redes de escolas, mercado editorial de livros didáticos e de sistemas apostilados, bem como parte da sociedade e, principalmente, responsáveis pelos estudantes que ainda consideram o ensino de língua dito tradicional como pertinente e satisfatório.

Todavia, tal articulação, em um documento curricular de referência é negativa, pois desestimula mudanças no ensino de língua materna, seja em nível macro, pelos sistemas e redes de ensino, seja em nível micro, por professores ou profissionais educacionais. Permitese, assim, a manutenção de práticas e propostas que vinham há mais de três décadas sendo desencorajadas e, paulatinamente, sendo revistas em processos de formação inicial e continuada de professores.

A BNCC também é problemática justamente por não especificar conceitos e termos. Isso corrobora a articulação harmoniosa de orientações pedagógicas e metodológicas contraditórias, mas, como já dito, dificulta o trabalho coletivo nas unidades escolares não apostiladas, uma vez que é possível adotar posições particulares coerentes com as preconizações de tal documento, que são muito amplas e abertas. Com isso, a padronização educacional intencionada pela BNCC pode também ser mais difícil de se efetivar.

No entanto, se olharmos para as especificações das competências e habilidades previstas para cada ano escolar, teremos detalhamentos bem demarcados sobre o que se espera para o processo de ensino e aprendizagem. Como mostrei, em relação ao ensino gramatical, o que se espera é o desenvolvimento de conhecimentos gramaticais tradicionais e normativos, de aplicação de categorizações e classificações morfológicas e sintáticas, além do domínio da escrita alfabética e da ortografia padrão.

Nesse sentido, apesar de a BNCC não especificar em nenhum momento delimitadamente o que seja gramática e como pretende que ocorra o ensino gramatical, nos trechos aqui analisados, percebe-se claramente que gramática e seu ensino pautam-se sobre a Gramática Tradicional e Normativa. Por um lado, essa não especificação cumpre a intenção do mencionado documento de harmonizar conhecimento científicos e escolares, sem forçar o estudo ou o aprimoramento dos docentes e dos profissionais da educação e, principalmente, das editoras de materiais didáticos. Por outro, desconsidera toda uma discussão científica e 
acadêmica sobre os estudos gramaticais, fortalecendo o senso comum de que gramática seja exclusivamente Gramática Tradicional e Normativa.

Há, contudo, um preço a ser pago com esse discurso harmônico da BNCC e que possivelmente se voltará contra professores, escolas e demais profissionais da educação, principalmente aqueles da rede pública: o desenvolvimento do conhecimento e da competência linguística de grande parte dos estudantes brasileiros não melhorará nas avaliações em larga escala, pois a base de ensino se mantém a mesma, gerando, portanto, os mesmos resultados. Além disso, contribui também para a crença descabida e corriqueira da maioria das pessoas de que, embora tenham estudado muitos anos a Língua Portuguesa na escola, não sabem falar ou não conhecem sua própria língua materna.

Destaco que se o professor ampliar seus conhecimentos teóricos sobre gramática, ele passará a compreender o ensino gramatical e a realizá-lo não exclusivamente por meio do ensino metalinguístico da língua, possibilitando que ele reflita, repense e justifique suas práticas de ensino em uma perspectiva mais reflexiva e menos prescritiva ou, ainda, descritiva. Também conseguirá compreender e, principalmente, justificar que está trabalhando com gramática em atividades de leitura e produção de texto, mesmo que tenha de utilizar a gramática tradicional. Com isso, efetivamente teremos o ensino de gramática contextualizada, pois o texto será o objeto de estudo e ensino das aulas de Língua Portuguesa. Ademais, o ensino gramatical será mais produtivo se conseguir contribuir para que o estudante reflita e compreenda o funcionamento linguístico, sem com isso sobrecarregá-lo com prescrições normativas, nomenclaturas ou categorizações descontextualizadas e idealizadas. Com isso, o professor está além do orientado sobre ensino gramatical na BNCC.

Destaco ainda que o problema não está no emprego da Gramática Tradicional. Essa é uma gramática teórica. Contudo, é preciso que o professor compreenda as limitações dessa gramática, que toma justamente a frase com objeto central de estudo. Também é preciso desvincular a ideia de que gramática como constituinte linguístico e gramática teórica não têm relação entre si. Com isso, o docente e os alunos conseguirão entender que a Gramática Tradicional trata da língua, mas não é a língua em si e que a gramática da língua não necessariamente coincide com as proposições da Gramática Normativa. Só isso, no meu entender, já proporcionaria certa reestruturação do ensino gramatical na Educação Básica brasileira.

\section{Notas}

1. Embora seja possível encontrar em diferentes trabalhos disponíveis na rede mundial de computares tal documento com datas de publicação que variam entre 2016 e 2018, a versão oficial disponibilizada no sítio eletrônico do Ministério da Educação (http://basenacionalcomum.mec.gov.br/images/BNCC_EI_EF_110518_versaofinal_site.pdf) não traz em seu corpo qualquer ficha catalográfica ou mesmo datação. Por isso, opto por referenciá-lo sem data de publicação.

2. A escolha desses currículos foi aleatória. Considerou-se apenas que já foram homologados e estão disponíveis pelas respectivas secretarias de educação em seus sítios eletrônicos.

3. A escolha dessa habilidade foi aleatória, não havendo qualquer motivação prévia para sua eleição.

4. Entre outros, destaco: Leis: $n^{\circ}$ 9.394/96 (LDB), n 13.005/14 (PNE); Resoluções: CNE/CP n 2/17, CNE/CP n 4/18; Pareceres: CNE/CBE n ${ }^{\circ} 7 / 10$, CNE/CP n ${ }^{\circ} 15 / 17$. 
5. Entre parênteses indico os subitens em que os trechos ocorrem na BNCC.

6. Aqui é interessante destacar que embora a BNCC apresente os itens de morfossintaxe e sintaxe, isso não acontece com morfologia.

7. Vale demarcar que, na BNCC, a análise, enquanto ação de reflexão sobre, deve incidir sobre a língua e outras semioses, por isso, há o eixo análise linguística/semiótica que procura evidenciar tal proposta.

\section{Referências}

ANTUNES, Irandé. Gramática contextualizada: limpando “o pó das ideias simples”. São Paulo: Parábola, 2014.

ANTUNES, Irandé. Muito além da gramática: por um ensino de línguas sem pedras no caminho. São Paulo: Parábola, 2007.

BRASIL. Lei no 9394, de 20 de dezembro de 1996. Estabelece as diretrizes e bases da educação nacional. Diário Oficial da União, Brasília, DF, 23 de dezembro de 1996. Disponível em: http://www.planalto.gov.br/ccivil_03/leis/19394.htm. Acesso em: 16 jan. 2021.

BRASIL. Ministério da Educação. Secretaria de Educação Fundamental. Parâmetros curriculares nacionais: terceiro e quarto ciclos do Ensino Fundamental - língua portuguesa. Brasília: MEC/SEF, 1998.

BRASIL. Conselho Nacional de Educação. Conselho Pleno. Resolução CNE/CP n 2, de 22 de dezembro de 2017. Institui e orienta a implantação da Base Nacional Comum Curricular, a ser respeitada obrigatoriamente ao longo das etapas e respectivas modalidades no âmbito da Educação Básica. Diário Oficial da União, Brasília, DF, 22 de dezembro de 2017. Disponível em: http://portal.mec.gov.br/conaes-comissaonacional-de-avaliacao-da-educacao-superior/323-secretarias-112877938/orgaos-vinculados82187207/53031-resolucoes-cp-2017. Acesso em: 18 nov. 2020.

BRASIL. Ministério da Educação. Secretaria de Educação Básica. Base Nacional Comum Curricular. Brasília: MEC, s/d. Disponível em: http://basenacionalcomum.mec.gov.br/. Acesso em: 16 nov. 2020.

BUNZEN, Clécio. Da era da composição à era dos gêneros: o ensino de produção de texto no ensino médio. In: BUNZEN, Clécio; MENDONÇA, Márcia. (org.). Português no ensino médio e a formação do professor. São Paulo: Parábola, 2006, p. 139-161.

CHIZZOTTI, Antônio. Pesquisa em Ciências Humanas e Sociais. 10. ed. São Paulo: Cortez, 2009.

FRANCHI, Carlos. Mas o que é mesmo gramática? In: SÃO PAULO (Estado). Secretaria de Educação. Coordenadoria de Estudos e Normas Pedagógicas. Língua Portuguesa: o currículo e a compreensão da realidade. São Paulo: SE/CENP, 1991, p. 43-59.

FRANCHI, Carlos. Criatividade e Gramática. In: POSSENTI, Sírio. (org.) Mas o que é mesmo gramática? São Paulo: Parábola, 2006, p. 34-101.

GIL, Antônio Carlos. Como elaborar projetos de pesquisa. São Paulo: Atlas, 2010

GOODSON, Ivor Frederick. Currículo: teoria e história. Petrópolis: Vozes, 1995.

ILARI, Rodolfo. A linguística e o ensino de língua portuguesa. São Paulo: Martins Fontes, 1992.

MACEDO, Elizabeth. “A Base é a base”. E o currículo o que é? In: AGUIAR, Márcia Angela.; DOURADO, Luiz Fernandes. (orgs.). A BNCC na contramão do PNE 2014-2024: avaliação e perspectivas. Recife: ANPAE, 2018, p. 28-33.

MARCONI, Marina de Andrade; LAKATOS, Eva Maria. Fundamentos de metodologia científica. São Paulo: Atlas, 2010. 
MINAS GERAIS. Secretaria Estadual de Educação. Comissão Estadual para Implementação da Base Nacional Comum Curricular. Currículo Referência de Minas Gerais. Belo Horizonte: SEE, s/d. Disponível em: https://drive.google.com/file/d/1ac2_Bg9oDsYet5WhxzMIreNtzy719UMz/view. Acesso em: 27 jan. 2021.

NEDER, Maria Lúcia Cavalli. Concepção de linguagem e ensino de língua portuguesa. Polifonia, Cuiabá, v. 1, n. 0, p. 71-89, 1993.

OLIVEIRA, Luciano Amaral. Coisas que todo professor de português precisa saber: a teoria na prática. São Paulo: Parábola, 2010.

PARANÁ. Secretaria Estadual de Educação. Referencial Curricular do Paraná: princípio, direitos e orientações. Curitiba: SEE, 2018. Disponível em: http://www.educadores.diaadia.pr.gov.br/arquivos/File/bncc/2018/referencial_curricular_parana_cee.pdf. Acesso em: 27 jan. 2021.

POSSENTI, Sírio. Por que (não) ensinar gramática na escola? Campinas: Mercado de letras, 1996.

ROJO, Roxane Helena. O texto no ensino-aprendizagem de línguas hoje: desafios da contemporaneidade. In: TRAVAGLIA, Luiz Carlos; FINOTTI, Luísa Helena Borges. et al. (org.) Gêneros de texto: caracterização e ensino. Uberlândia: EDUFU, 2008, p. 9-43.

SÃO PAULO (Estado). Secretaria Estadual de Educação. Coordenadoria de Estadual da SEE. Currículo Paulista. São Paulo: SEE, s/d. Disponível em: https://efape.educacao.sp.gov.br/curriculopaulista/. Acesso em: 27 jan. 2021.

TRAVAGLIA, Luiz Carlos. Gramática e interação: uma proposta para o ensino de gramática. São Paulo: Cortez, 2009.

\section{Correspondência}

Hermes Talles dos Santos Brunieri: Graduado em Letras, mestre e doutor em Linguística. Professor Adjunto do Departamento de Metodologia da Educação, área de Linguagens, do Centro de Educação da Universidade Federal da Paraíba.

ORCID: 0000-0003-0048-0377

E-mail: hermes.santos@academico.ufpb.br

Texto publicado em Currículo sem Fronteiras com autorização do autor. 